\title{
Head and Neck Cancer pN3b TNM Finding v8
}

National Cancer Institute

\section{Source}

National Cancer Institute. Head and Neck Cancer pN3b TNM Finding v8. NCI Thesaurus. Code C132653.

Head and neck cancer with metastasis in a single ipsilateral lymph node larger than $3 \mathrm{~cm}$ in greatest dimension and $\mathrm{ENE}(+)$; or metastases in multiple ipsilateral, contralateral, or bilateral lymph nodes, any with ENE(+). (from AJCC 8th Ed.) 